Kumawula, Vol. 3, No.3, Desember 2020, Hal 387 - 397

DOI: https://doi.org/10.24198/kumawula.v3i3.27149

ISSN 2620-844X (online)

Tersedia online di http://jurnal.unpad.ac.id/kumawula/index

\title{
INTEGRASI POTENSI WIRAUSAHA DALAM MEWUJUDKAN CITAMAN SEBAGAI DESA WISATA
}

\author{
Desi Yunita $^{1^{*}}$, Bintarsih Sekarningrum ${ }^{2}$ \\ ${ }^{1,2}$ Departemen Sosiologi, Fakultas Ilmu Sosial dan Ilmu Politik, Universitas Padjadjaran \\ *Korespondensi : desi.yunita@unpad.ac.id

\section{INTEGRATION OF ENTREPRENEURS POTENCY IN REALIZING CITAMAN VILLAGE AS A TOURISM VILLAGE}

\begin{abstract}
This social mapping is intended to find out the potential of entrepreneurs in Citaman Village, which will support the development plan of tourism villages. In this activity several mapping techniques were used, including sketch maps, transects, and FGDs. This mapping found potential entrepreneurs who have the potential to become destinations to support the development of village tourism including dragon fruit plantations, coffee plantations, swimming pools, fishing ponds, sheep agility competitions, traditional dances, and pencak silat competitions. In addition, this social mapping also found several things that could become obstacles. First, the level of participation of the whole community is still very low due to the fact that the planned development of this tourism village has not been socialized to the entire community. The structure of society has also not been directed to become the structure of a tourism society. Therefore, although this mapping has succeeded in providing a description of the potential for tourism, socialization and adjustment needs to be done in the community before the plan is implemented.
\end{abstract}

Keywords: Mapping, Entrepreneurial Potential, Tourism Village

\begin{abstract}
ABSTRAK
Pemetaan sosial ini ditujukan untuk mengetahui potensi wirausaha di Desa Citaman yang akan mendukung rencana pengembangan desa wisata. Pada kegiatan ini digunakan beberapa teknik PRA untuk dapat mengetahui potensi yang ada di Desa Citaman khususnya wirausaha, teknik tersebut diantaranya peta sketsa, transek, dan FGD. Proses pemetaan ini, menemukan beberapa potensi wirausaha yang juga berpotensi untuk dikembangkan menjadi destinasi dalam rangka mendukung pengembangan wisata desa diantaranya, perkebunan buah naga, perkebunan kopi, kolam renang, kolam pemancingan, lomba ketangkasan domba, seni tari, dan kesenian pencak silat. Kegiatan ini juga menemukan beberapa hal yang dapat menjadi penghambat. Seperti, belum tersebarnya gagasan pengembangan desa wisata ini pada seluruh masyarakat, yang berpengaruh pada masih minimnya dukungan dan partisipasi masyarakat. Selain itu, belum adanya penyesuaian pada struktur masyarakat menjadi struktur pariwisata juga diyakini akan memberikan hambatan bagi rencana pengembangan desa wisata ini. Secara keseluruhan pemetaan ini memberikan gambaran bagi pemerintah desa Citaman sebagai acuan pengembangan desa wisata melihat dari potensi dan masalah yang ada di Desa Citaman.
\end{abstract}

Kata kunci: Pemetaan, Potensi wirausaha, Desa Wisata.

\section{PENDAHULUAN}

Ateljevic dan Stephen Page (2009:1), mengemukakan bahwa pengembangan pariwisata menyediakan jalan untuk pengembangan ekonomi secara keseluruhan dan dorongan untuk kewirausahaan lokal. Hal itu karena pariwisata merupakan kegiatan yang langsung bersentuhan dan melibatkan partisipasi masyarakat secara luas terutama pada wilayah ingin dijadikan sebagai tujuan wisata tersebut. Keterlibatan masyarakat ini akan memberikan dampak positif bagi masyarakat yang terlibat baik secara langsung 
ataupun tidak langsung. Selain berdampak positif secara ekonomi bagi masyarakat, pariwisata juga menyebabkan perkembangan masyarakat secara sosial, dan budaya. Semangat pariwisata yang memberikan pelayanan kepada wisatawan, juga diyakini mendorong terbentuknya masyarakat yang terbuka, memiliki semangat melayani, sekaligus juga berpotensi menumbuh kembangkan dan melestarikan tradisi-tradisi budaya yang ada sebagai upaya meningkatkan daya tarik bagi pengunjung wisata di desa.

Desa Wisata adalah daerah dengan area tertentu dan memiliki potensi atraksi wisata yang unik dan komunitas masyarakatnya dapat menciptakan tempat wisata dan fasilitas pendukung untuk menarik wisatawan berkunjung, pertumbuhan fasilitas akomodasi juga termasuk yang disediakan oleh masyarakat lokal (Hamzah, A.S. \& M. Irfan, 2018). Merujuk pada pendapat tersebut, maka dalam mengembangkan desa wisata, sangat penting untuk mengetahui potensi apa saja yang dimiliki oleh suatu desa, hingga dapat dikembangkan menjadi desa wisata. Priasukmana \& Mulyadin (2001), menjelaskan bahwa desa wisata merupakan suatu kawasan pedesaan yang menawarkan keseluruhan suasana yang mencerminkan keaslian pedesaan baik dari kehidupan sosial ekonomi, sosial budaya, adat istiadat, keseharian, memiliki arsitektur bangunan dan struktur tata ruang desa yang khas, atau kegiatan perekonomian yang unik dan menarik serta mempunyai potensi untuk dikembangkannya berbagai komponen kepariwisataan, misalnya atraksi, akomodasi, makanan-minuman, Cindera-mata, dan kebutuhan wisata lainnya.

Upaya pengembangan Desa Citaman sebagai desa wisata ini tidak terlepas dari semakin berkembangnya potensi wirausaha berbasis wisata yang ada di Desa Citaman. Pengembangan desa wisata ini juga dilakukan sebagai upaya menghambat terjadinya perubahan fungsi lahan yang ada di Desa Citaman. Perubahan fungsi lahan yang dipengaruhi oleh semakin terbukanya desa karena pembangunan infrastruktur, bertambahnya penduduk, dan beralihnya pekerjaan masyarakat. sehingga, dengan pengembangan desa wisata dan mendorong semakin berkembangnya wirausaha berbasis wisata yang dikembangkan di Desa Citaman ini, terutama pada kelompok usia muda Desa Citaman. dan disebabkan oleh semakin banyak penduduk usia muda dan lebih berpendidikan yang memilih bermigrasi ke kota-kota atau memilih bekerja pada bidang pekerjaan yang lain selain pertanian, serta karena terjadinya penurunan jumlah lahan pertanian yang ada di desa karena berubah menjadi areal peruntukkan lain utamanya pemukiman. Pengamatan yang dilakukan memperlihatkan bahwa banyak generasi muda yang memilih untuk bekerja di beberapa sektor pekerjaan selain pertanian, di antaranya tukang ojek, kuli bangunan, buruh pabrik, dan lainnya.

Sebagai upaya menghambat alih fungsi lahan tersebut, digagaslah Desa Wisata Citaman ini, dengan harapan dengan mengembangkan desa wisata ini dapat mendorong semakin berkembangnya wirausaha produktif berbasis wisata tersebut, sehingga dapat menjadi daya tarik ekonomi bagi masyarakat untuk memulai wirausaha yang akan mendukung pariwisata desa tersebut. selain itu, dengan menjadi desa wisata diharapkan juga dapat menumbuhkan kreativitas masyarakat untuk mengembangkan wisata yang tentunya akan mendukung wirausaha yang dikembangkan oleh masyarakat. semakin meningkat kunjungan wisata masyarakat, maka peluang untuk semakin meningkatnya pendapatan masyarakat secara ekonomi juga akan semakin terbuka (Buchari et al., 2019). Selain ditujukan untuk meningkatkan wirausaha di desa, pengembangan desa wisata ini juga didasari oleh keadaan geografis mengenai kondisi desa yang berada di jalur perlintasan dari dan menuju beberapa tempat yang telah dikenal sebagai daerah tujuan wisata yang ada di Kabupaten Garut, maupun tasik yang diketahui memiliki banyak tempat wisata. Sehingga, dengan mengembangkan desa Citaman sebagai Desa Wisata diharapkan akan menjadi alternatif baru lokasi wisata yang bisa dikunjungi oleh masyarakat terutama para wisatawan yang ingin berkunjung ke wilayah Garut ataupun Tasik. 
Gagasan pengembangan desa wisata ini sejalan dengan apa yang dikemukakan (Abdoellah et al., 2019; Briedenhann dan Wickens, 2004; Gulean et al., 2009; Dimitrovski et.al., 2012) bahwa wisata pedesaan menawarkan solusi yang memungkinkan untuk beberapa masalah yang terkait dengan hilangnya peluang ekonomi dan penurunan populasi yang menyertai pertanian yang memudar. Banyak pemerintah atau pemerintah daerah telah merangkul pariwisata pedesaan sebagai kesempatan untuk membawa uang baru ke daerah pedesaan, merangsang pertumbuhan, menyediakan kesempatan kerja dan dengan demikian mulai menghentikan penurunan pedesaan. Selain itu, dengan menjadikan desa sebagai salah satu destinasi wisata banyak peluang termasuk akomodasi dan penyediaan layanan, serta menampilkan budaya lokal dan warisan budaya telah mendorong desa menjadi aktif, (Evans dan Pickel Chevaliers, dalam Dashper, 2015).

Pariwisata adalah salah satu sektor ekonomi yang tingkat pertumbuhannya sangat cepat di Indonesia. Tahun 2009, pariwisata menempati urutan ketiga dalam memberikan penerimaan devisa di bawah minyak/gas bumi dan minyak kelapa sawit. Merujuk pada data tahun 2010, diketahui bahwa jumlah wisatawan mancanegara yang datang ke Indonesia sebesar 7 juta lebih atau tumbuh sebesar 10, 74\% dibanding tahun 2009. Sedangkan untuk desa wisata, diketahui bahwa pada tahun 2018 terdapat 1734 Desa wisata. Namun, meskipun desa wisata juga terus mengalami kemajuan, dan pariwisata secara umum juga mengalami peningkatan. Namun, kemajuan tersebut masih sedikit sekali memberikan manfaat bagi masyarakat sekitar. Hal tersebut dipengaruhi oleh kesadaran masyarakat yang masih rendah. Sehingga tidak semua masyarakat mampu untuk melihat kesempatan ekonomi yang ditawarkan dari pengembangan pariwisata desa. Selain itu, meskipun kemajuan pariwisata belum memberikan manfaat bagi masyarakat, namun peluang di sektor pariwisata masih terbuka bagi masyarakat, dengan catatan bahwa masyarakat desa khususnya harus menjadi pelaku langsung dari bisnis pariwisata tersebut.

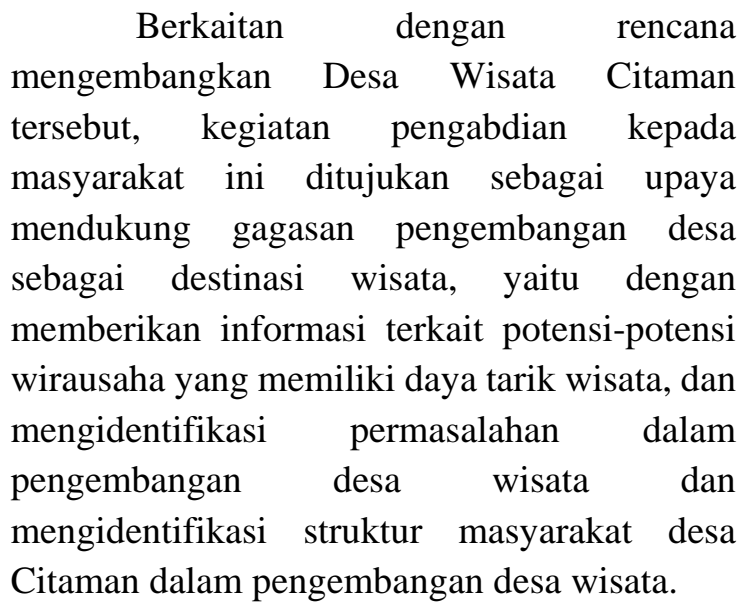

\section{Konsep Integrasi Potensi}

Secara umum integrasi dapat dipahami sebagai pembauran atau proses penyatuan sesuatu hingga menjadi kesatuan yang utuh. Sehingga dapat pula dimaknai bahwa integrasi merupakan sebuah proses penyesuaian unsurunsur yang berbeda dalam masyarakat sehingga menjadi kesatuan. Adapun, integrasi sosial lebih berfokus pada sejauh mana masyarakat mengadaptasi kebiasaan-kebiasaan baru, hubungan sosial, dan praktik sehari-hari (Jacob Vigdor, 2008) yang berkaitan dengan wirausaha dan pengembangan desa wisata, sehingga integrasi wisata adalah sebuah proses penyatuan potensi-potensi wirausaha yang ada di desa ke dalam struktur pariwisata, sehingga makin memperkaya konten pariwisata yang ditawarkan di Desa.

Marshall (1998:319) mengutip Talcott Parson menyebutkan bahwa dalam teori fungsional, istilah integrasi adalah fundamental, dan menggambarkan 'mode hubungan unit-unit sistem berdasarkan sistem dan membuatnya tidak mungkin untuk mempertahankan stabilitasnya, dan, di sisi lain, untuk "bekerja sama" untuk mempromosikan fungsinya sebagai satu kesatuan, dan dalam tradisi teoretis lainnya, sering digunakan lebih longgar sebagai sinonim untuk konsensus sosial. Selanjutnya, Scott dan Marshall (2009:614) juga menyandingkan antara integrasi sosial dan integrasi sistem. Dimana, integrasi sosial mengacu pada prinsip-prinsip di mana individu atau aktor terkait satu sama lain dalam masyarakat. Scott dan Marshall (2009:614) mengemukakan bahwa sumber utama integrasi sosial yang telah diidentifikasi oleh para sosiolog dalam masyarakat kapitalis maju 
adalah sistem kelas. Dalam masyarakat feodal, sistem perkebunan memainkan peran yang setara, seperti halnya kasta dalam masyarakat India. Secara umum (mengikuti ajaran Max Weber tentang stratifikasi sosial) masyarakat berbasis status cenderung mengarah pada bentuk integrasi sosial yang harmonis, dan masyarakat kelas ke bentuk konflik sosial integrasi sosial. Sedangkan integrasi sistem disisi lain, adalah referensi ke cara di mana berbagai bagian sosial sistem (institusinya) saling terkait. Teori perubahan sosiologis yang memadai harus berupaya menghubungkan integrasi sosial dengan integrasi sistem.

Namun, dalam esai asli Lockwood pada integrasi sosial dan integrasi sistem, ia mencatat bagaimana teori konflik menekankan konflik antara kelompok pelaku sebagai motor basis dasar perubahan sosial. Sementara fungsionalis normatif meremehkan peran aktor dan berusaha untuk menekankan hubungan (fungsional dan disfungsional) antara lembaga-lembaga masyarakat. Bagi Lockwood tidak ada pendekatan yang memadai, tepatnya karena masing-masing berurusan dengan hanya satu sisi badan versus masalah struktur. Lockwood (dalam Scott dan Marshall, 2009:615) juga mencatat bagaimana teori Karl Marx tentang masyarakat kapitalis merujuk pada pertentangan kelas yang berkembang (integrasi sosial) yang terkait dengan kontradiksi antara kekuatan produksi dan hubungan produksi (integrasi sistem). Artinya bagi marx, kontradiksi sistem terkait dengan tindakan kelompok yang merespons kontradiksi dengan berupaya mengubah atau melestarikan masyarakat yang ada. Ini adalah kontradiksi ditingkat sistem yang mengarah pada konflik sosial (kelas): Integrasi sistem terkait dengan integrasi sosial.

Scott dan Marshall (2009:614) juga mengemukakan bahwa baru-baru ini, Anthony Giddens juga berusaha menggunakan perbedaan ini. Awalnya ia menggunakannya dalam cara yang mirip dengan Lockwood, tetapi dalam karya terbarunya ia berusaha menggunakannya sebagai cara untuk mengganti perbedaan mikro versus makro dan, dengan demikian, masalah agensi dan struktur. Integrasi sosial mengacu pada situasi dimana aktor secara fisik 'hadir bersama' dan integrasi sistem ke tempat mereka tidak berada. Ini tidak memuaskan karena interaksi tatap muka (copresence) tidak terbatas pada proses mikro. Secara singkat, penggunaan analisis Lockwood dimaksudkan untuk menjelaskan bahwa perbedaan antara integrasi sosial dan integrasi sistem adalah fundamental untuk teori apa pun yang berusaha menyatukan analisis tingkat mikro dan makro. Seperti terlihat pada tulisantulisan Jurgen Habermas (dalam Scott dan Marshall (2009:615) yang berisi perbedaan yang banyak persamaannya antara kehidupan dunia dan sistem sosial.

Sedangkan, Kun Maryati dan Juju Suryawati (2014:140) menyebutkan bahwa integrasi sosial merupakan proses penyesuaian unsur-unsur yang berbeda di dalam masyarakat sehingga menjadi satu kesatuan. Unsur-unsur yang berbeda tersebut dapat meliputi perbedaan kedudukan sosial, ras, etnik, agama, Bahasa, kebiasaan, sistem, nilai dan norma. Agar integrasi sosial tersebut berhasil, Ogburn dan Nimkoff (1964) mengemukakan bahwa terdapat beberapa hal yang menjadi syarat berhasilnya suatu integrasi sosial diantaranya adalah, pertama, adanya perasaan berhasil saling mengisi kebutuhan-kebutuhan antar anggota satu dengan yang lain. Kedua, masyarakat berhasil menciptakan kesepakatan (consensus) bersama mengenai norma dan nilai sosial yang dikembangkan sebagai pedoman interaksi antar sesama anggota masyarakat, ketiga, berlakunya norma dan nilai sosial tersebut sangat lama dan tidak mengalami perubahan sehingga dapat dipergunakan secara terus menerus dalam proses interaksi sosial antar sesama masyarakat.

Oleh karena itu, maka integrasi potensi wirausaha dan pariwisata ini juga memiliki maksud agar terjadi pembauran sehingga terjadi perubahan pada pelaku wirausaha yang ditunjukkan dengan sikap menjadi lebih peduli dan terbuka pada perkembangan proses pariwisata yang akan dilakukan di Desa Citaman. Karena, dalam integrasi tersebut juga terdapat kerja sama dari seluruh anggota masyarakat khususnya pelaku usaha yang ada di Desa terkait pengembangan sebagai desa wisata, sehingga berkembang konsensus dan 
nilai-nilai yang sama dimasyarakat dalam melihat atau mengembangkan wisata di desa ini.

\section{METODE}

Kegiatan ini menggunakan metode pemetaan untuk menggambarkan kondisi wilayah, dan kondisi masyarakat secara sosial. Teknik pengumpulan data dilakukan dengan menggunakan PRA (Participatory rural Appraisal), diskusi kelompok terfokus (FGD) dan pengumpulan data serta informasi tentang masyarakat yang ada di Desa Citaman yang ditujukan untuk mengetahui apa saja yang akan mendukung atau menghambat upaya pengembangan desa wisata ini melalui observasi. Pemetaan dan penggambaran kondisi sosial masyarakat ini disesuaikan dengan beberapa potensi wirausaha yang dikembangkan di Desa dan memiliki potensi sebagai destinasi wisata di Desa Citaman. Selanjutnya, juga melihat beberapa wilayah desa yang memiliki potensi dikembangkan menjadi wisata. setelah mendapatkan gambaran mengenai beberapa potensi wirausaha dan wisata yang ada di desa Citaman tersebut beberapa potensi wirausaha dan wisata tersebut diintegrasikan. Sehingga setiap informasi dan data yang dikumpulkan selalu disesuaikan dengan aspek-aspek yang menunjang pengembangan desa wisata, yang menggambarkan potensi-potensi yang ada di desa yang memiliki kesesuaian dengan komponen pariwisata, yang mengacu pada apa yang dikemukakan oleh (Kemenpar, 2007) yaitu, aksesibilitas, atraksi, amenitas, kelembagaan, dan masyarakat. sedangkan lima unsur pembentuk pariwisata adalah objek, aksesibilitas, fasilitas pendukung, kelembagaan masyarakat, pelaku industri (Sunaryo, 2013:160). Oleh karenanya, hasil pemetaan ini akan memberikan gambaran bahwa gagasan pengembangan desa wisata tersebut memungkinkan untuk di realisasikan merujuk pada potensi-potensi wirausaha yang ada. Oleh karena itu, kegiatan ini dapat juga disebut sebagai profiling atau membuat gambaran menyeluruh mengenai kondisi potensi, dan masalah yang ada di desa Citaman. Pada kegiatan pemetaan ini juga dilakukan pemetaan sosial yang diperlukan untuk mengetahui sejauh mana struktur masyarakat dan lembagalembaga yang ada di Desa Citaman mendukung pengembangan desa wisata. sehingga kegiatan pemetaan ini selain mendapatkan informasi mengenai potensi juga dapat berperan sebagai social profiling atau pembuatan profil suatu masyarakat (Netting, Kettner dan McMurtry 1993).

\section{HASIL DAN PEMBAHASAN}

Secara kewilayahan Desa Citaman masuk dalam wilayah kecamatan Nagrek Kabupaten Bandung. Desa Citaman ini secara langsung berbatasan dengan beberapa desa diantaranya: Desa Tanjungwangi Kecamatan Cicalengka di sebelah utara; Desa Nagreg Kendang Kecamatan Nagreg di sebelah timur; Desa Ganjar Sabar Kecamatan Nagreg di Sebelah Selatan; dan Desa Nagrok Kecamatan Cicalengka di sebelah Barat. Lokasi desa ini cukup strategis karena terletak di jalan lintas provinsi yang menghubungkan Jawa Barat dan Jawa Tengah, yang sangat ramai dilintasi masyarakat apalagi ketika musim liburan tiba. Selain itu, ketika musim liburan tiba jalan ini merupakan jalan utama bagi masyarakat yang ingin berwisata menuju kabupaten garut. Selain itu, sebelum masuk ke wilayah Desa Citaman ini juga sangat banyak dijumpai, restoranrestoran besar yang berfungsi sebagai area beristirahat (rest area) kendaraan-kendaraan dari Jakarta menuju ke Garut ataupun Tasikmalaya, menjadikan desa ini memiliki kelebihan berupa lokasi yang strategis untuk dikembangkan sebagai desa wisata. Dengan luas wilayah mencapai 342,596 hektar, yang terbagi menjadi 4 dusun dan $15 \mathrm{RW}$, serta jumlah penduduk sebesar 8.308 jiwa (Monografi Desa Citaman, 2019).

Mata pencaharian masyarakat yang utama adalah sebagai petani, meskipun saat ini jumlah masyarakat yang bekerja sebagai petani tidak lagi mendominasi. Saat ini banyak masyarakat khususnya yang berusia di bawah 50 tahun merupakan karyawan swasta atau buruh pada pabrik-pabrik tekstil dan garmen yang banyak tersebar di wilayah kecamatan Nagreg dan Cicalengka. Pekerjaan yang banyak 
mendominasi juga pada sektor informal seperti tukang ojek, supir angkot, atau buruh bangunan. Jika dilihat secara Pendidikan, mayoritas warga desa Citaman merupakan tamatan SLTP dan sebagian besar tidak melanjutkan ke jenjang Pendidikan yang lebih tinggi. Berubahnya komposisi sumber pendapatan masyarakat dari bertani menjadi karyawan atau buruh dan sektor informal tersebut memperlihatkan bahwa fenomena pengotaan desa-desa juga dialami oleh Desa Citaman.

Sejauh ini juga diketahui bahwa pemerintahan desa saat ini memiliki perhatian tinggi pada pengembangan desa, selain kelembagaan, juga telah dibentuk media-media penggerak untuk mendukung pengembangan wirausaha ataupun wisata di desa Citaman seperti BUMDes, yang mana badan usaha milik desa tersebut memiliki beberapa unit usaha yang telah berjalan, di antaranya, usaha oleholeh yang merupakan kerajinan dari masyarakat, juga sudah ada pusat kuliner yang ditujukan untuk menjadi sentra kuliner di lingkungan desa yang juga menjadi daya tarik bagi masyarakat dari luar desa atau wisatawan, juga sudah ada lembaga yang secara khusus menggali tradisi kesenian yang ada di desa, yang memungkinkan untuk ditampilkan. Gambaran itu semua memperlihatkan bahwa secara kelembagaan upaya pengembangan desa wisata tersebut sangat mungkin untuk segera direalisasikan. Meskipun begitu, rencana pengembangan wisata di Desa Citaman ini bukan tanpa kendala, beberapa kendala yang memungkinkan dapat menjadi penghambat di antaranya adalah masyarakat belum sepenuhnya mengetahui secara pasti tentang rencana pengembangan desa menjadi tujuan wisata, hal tersebut masih terlihat dari sebagian besar warga masyarakat di Desa Citaman yang belum mengetahui secara pasti tentang rencana pengembangan desa wisata tersebut. Hal tersebut sangat terlihat terutama pada belum dilakukannya penataan lingkungan di sekitar pemukiman masyarakat. Idealnya jika rencana pengembangan desa wisata tersebut sudah dikemukakan secara terbuka oleh masyarakat maka masyarakat akan mendukung upaya tersebut dengan melakukan penataan lingkungan sekitar rumah mereka, atau mengembangkan usaha-usaha yang akan mendukung rencana pengembangan desa wisata tersebut, seperti dengan mengembangkan taman-taman tematik ditingkat RT atau RW dengan begitu maka setiap pengunjung yang datang ke desa Citaman sudah mendapatkan kesan bahwa desa Citaman adalah desa wisata. Akan tetapi, meskipun masih ditemui beberapa hal yang dapat menjadi kendala atau penghambat, melalui upaya yang sosialisasi terus menerus hambatan tersebut dapat disinergikan dengan rencana pengembangan desa menjadi desa wisata tersebut. Secara khusus adalah dengan mengupayakan agar seluruh masyarakat dapat berpartisipasi dalam pengembangan wisata desa ini.

\section{Pemetaan Sosial dan pemetaan Potensi Wirausaha di Desa Citaman}

Pemetaan sosial ini dilakukan untuk mengetahui dan mengenali lebih dalam mengenai kondisi masyarakat desa Citaman. Selain itu kegiatan pemetaan ini dikhususkan sebagai salah satu bentuk dukungan kepada Desa Citaman terkait dengan rencana pengembangan desa Citaman sebagai Desa Wisata. Dari proses pemetaan sosial ini akan diketahui secara lebih mendalam mengenai karakteristik, tradisi, dan potensi yang ada didesa Citaman. Di antaranya adalah diketahui bahwa saat ini di Desa Citaman telah ada pengembang perumahan yang membangun perumahan berkonsep kluster dan juga pengembang perumahan yang berkonsep vila yang wilayahnya berbatasan dengan wilayah hutan. Meskipun lahan pertanian masih banyak tersedia, tetapi mayoritas masyarakat telah beralih profesi sebagai karyawan atau buruh pabrik khususnya pada masyarakat yang berusia 20 - 45 tahun. Adanya pengembang perumahan di Desa Citaman ini menjadi catatan tersendiri bagi pemerintah desa karena sangat memungkinkan pemukiman tersebut akan mengalami perkembangan. Oleh karena itu, untuk menghindari alih fungsi lahan pertanian tersebut, dan untuk meningkatkan perekonomian masyarakat dan mendorong perkembangan desa secara positif, pemerintah telah mencanangkan pengembangan desa Citaman menjadi desa wisata. 


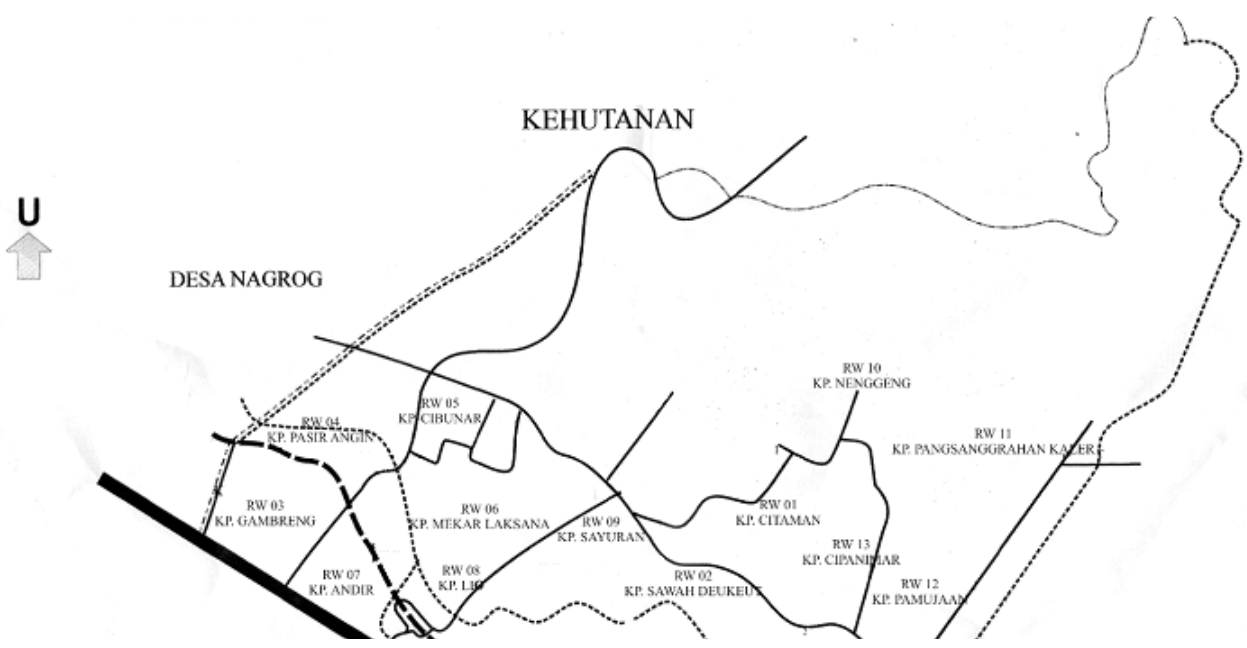

Tabel 1. Potensi wirausaha dan Potensi alam desa Citaman

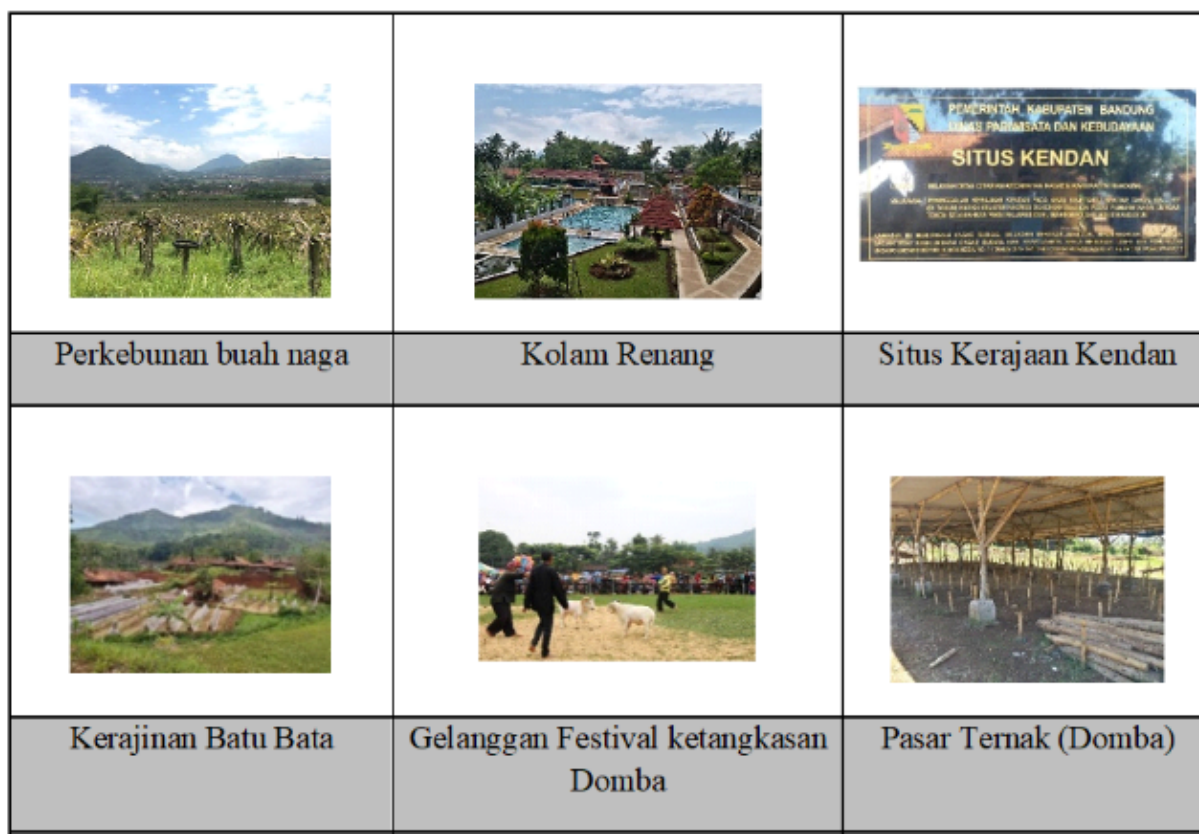

Denah atau gambaran wilayah tersebut memperlihatkan pola pemukiman masyarakat yang ada di Desa Citaman mengikuti jalan, sedangkan lahan pertanian masih cukup terbuka di sebelah barat desa. Selanjutnya, pemetaan wirausaha yang saat ini ada di Desa Citaman menunjukkan bahwa pengembangan desa wisata sangat memungkinkan dilakukan di desa Citaman, dilihat dari jenis-jenis wirausaha yang telah ada dan berkembang di Desa Citaman tersebut, beberapa jenis wirausaha. 


\begin{tabular}{|l|c|c|}
\hline & & \\
\hline & & \\
\hline & Situs bukit batu & Pemandangan alam \\
\hline Pembibitan tanaman hutan & & \\
\hline Areal pertanian & Tugu batu kursi & Kerajinan olahan pisang \\
\hline
\end{tabular}

Hasil pemetaan wirausaha yang ada di desa Citaman tersebut memperlihatkan bahwa beberapa wirausaha yang ada di desa, dan didukung dengan potensi alam dan potensi pertanian yang sudah ada maka pengembangan desa Citaman menjadi desa wisata sangat memungkinkan, karena beberapa potensi wirausaha yang ada tersebut sudah mencakup dalam lima unsur pembentuk destinasi. Akan tetapi meskipun pengembangan tersebut memungkinkan untuk dilakukan, diketahui pula bahwa mayoritas wirausaha yang ada di Desa Citaman tersebut terletak di pemukiman masyarakat, sehingga untuk mengembangkan wirausaha menjadi bagian dari desa wisata partisipasi dari seluruh masyarakat desa Citaman sangat diperlukan. Sedangkan seperti diketahui bahwa sebaran pemukiman masyarakat tersebut paling banyak berada di wilayah pusat desa dan selanjutnya menyebar ke pinggir seperti yang ditunjukkan pada gambar 2 berikut ini:

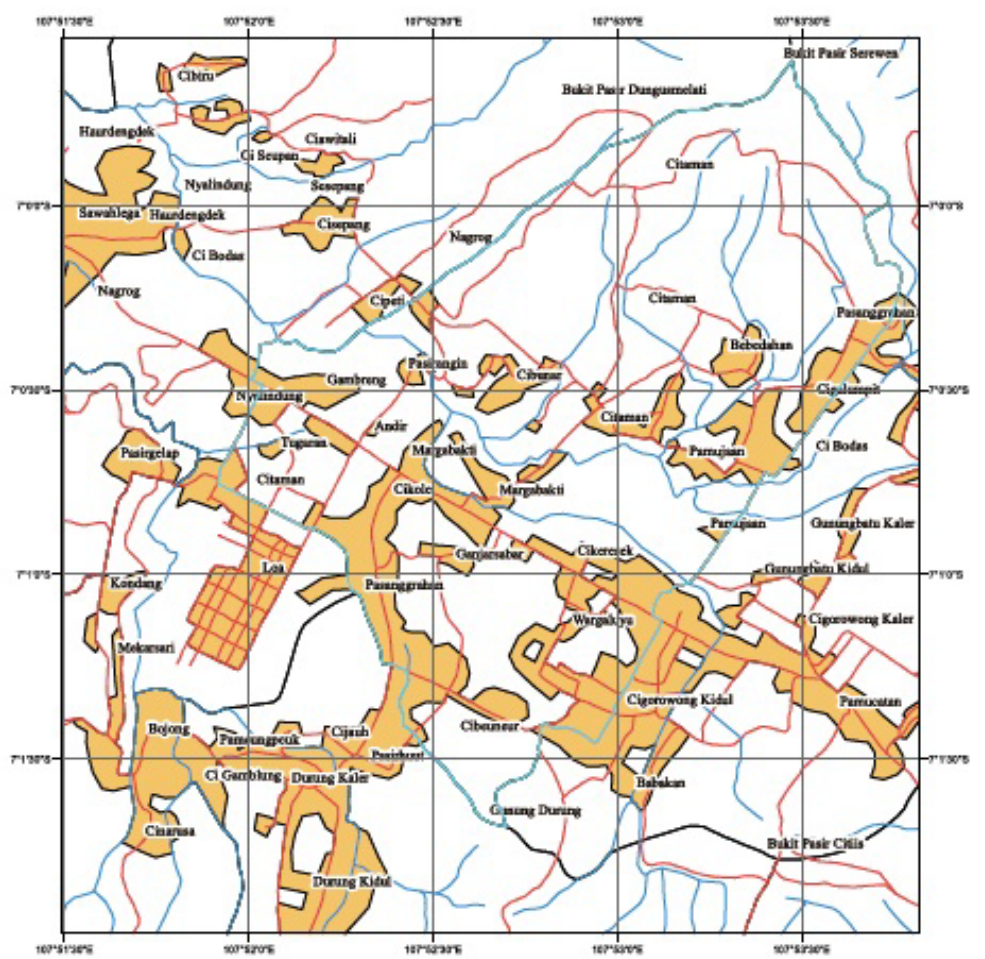

\section{PETA DASAR}

Desa Citaman, Kecamatan Nagreg, Kabupaten Bandung, Jawa Barat
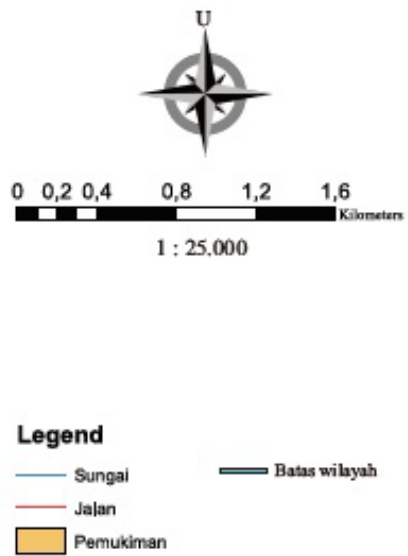

Gambar 2. Peta Persebaran pemukiman Masyarakat di Desa Citaman 
Melihat pola pemukiman masyarakat dan lokasi-lokasi wirausaha yang berada di antara pemukiman masyarakat maka keberhasilan pengembangan desa wisata yang terintegrasi potensi-potensi wirausaha di desa sangat bergantung dengan partisipasi dan penerimaan warga terhadap rencana tersebut. Semakin banyak masyarakat yang berpartisipasi maka akan semakin cepat terbentuknya desa wisata tersebut.

\section{Integrasi Rencana Pengembangan Desa Wisata - Struktur Masyarakat}

Mengembangkan Desa menjadi Desa Wisata bukanlah suatu proses yang instan, pada prosesnya perlu dilakukan perubahan dan penyesuaian, terutama pada masyarakat yang akan menjadi pelaku langsung dari rencana pengembangan desa wisata tersebut. Dalam perspektif sosiologi proses integrasi tersebut setidaknya harus merupakan upaya saling melengkapi antar struktur-struktur yang berinteraksi. Dalam konteks rencana pengembangan desa wisata di desa Citaman ini interaksi antar struktur tersebut terjadi antara struktur pemerintah desa dan struktur masyarakat. Dimana dalam mendukung rencana tersebut pemerintah desa akan mempersiapkan infrastruktur penunjang, mempersiapkan bentuk-bentuk atraksi, mempersiapkan fasilitas, dan mempersiapkan struktur masyarakat. Sedangkan masyarakat desa, jika sudah menerima rencana tersebut maka akan memberikan dukungan dalam pengembangan wisata tersebut. Sehingga akan terbentuk struktur masyarakat pariwisata di Desa Citaman.

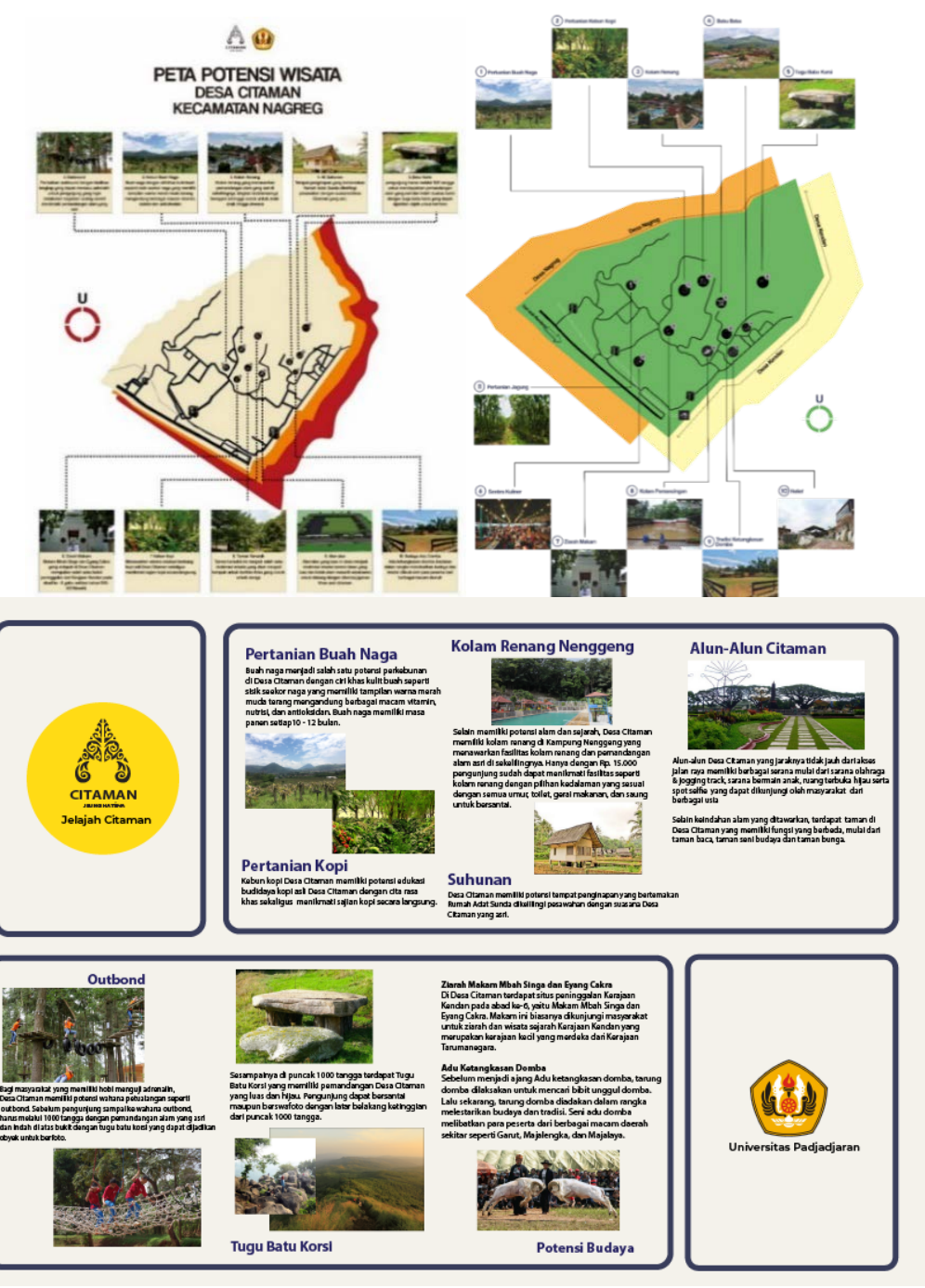

Gambar 3. Simulasi Peta Potensi Pariwisa Desa Citaman 
Struktur dalam masyarakat pariwisata setidaknya memuat beberapa hal seperti: hubungan sosial yang mencakup kedudukan dan peran serta masyarakat dalam proses pariwisata; lembaga sosial yang meliputi seperangkat pola perilaku yang distrandardisasi sesuai konsep pariwisata, nilai-nilai yang mendukung, tradisi, ritual, upacara dan simbol pemaknaan; institusi sosial pariwisata yaitu organisasi sosial yang dibentuk dalam rangka mendukung pariwisata; pranata sosial yang mencakup aturan main dalam pariwisata; stratifikasi sosial yang menguraikan tentang bagaimana dapat menjadi proses penyambungan dan perubahan sistem perbedaan status dimasyarakat dan perubahan sosial yang melihat bagaimana pariwisata berperan dalam mendorong perubahan sosial di masyarakat.

Integrasi pengembangan pariwisata Desa Citaman sangat mungkin terjadi jika setiap masyarakat dapat memperoleh manfaat dari pengembangan pariwisata tersebut, dan dapat memenuhi kebutuhan-kebutuhannya, jika model pariwisata desa tersebut dapat menjamin hal tersebut maka sangat mungkin integrasi tersebut dapat terjadi, dengan munculnya kesepakatan-kesepakatan antar masyarakat yang menjadi pedoman interaksi dalam upaya mendukung pengembangan pariwisata.

\section{KESIMPULAN DAN SARAN}

Beberapa hal yang dapat disimpulkan dari kegiatan ini adalah sebagai berikut :

1. Pemetaan potensi memperlihatkan potensi wirausaha yang ada di desa Citaman yang terkorelasi dengan pengembangan desa wisata. Beberapa potensi tersebut di antaranya: perkebunan buah naga, kolam pemancingan lele, kolam ikan, pabrik batu bata, kebun jagung, kebun kopi, kolam renang. Dari semua potensi wirausaha yang ada tersebut pengembangan desa wisata hanya memerlukan pengemasan (packaging) dan penyesuaian yang akan memberikan gambaran alur pariwisata di desa.
2. Selain potensi wirausaha, potensi masalah yang terlihat adalah masih rendahnya partisipasi masyarakat, hal tersebut terjadi karena sosialisasi yang belum maksimal dari desa mengenai pengembangan desa wisata tersebut.

3. Pemetaan ini juga menjadi justifikasi bagi pemerintah desa mengintegrasikan gagasan membangun desa wisata, karena dengan pemetaan beberapa potensi wirausaha peluang pengembangan desa wisata semakin terlihat

4. Desa Citaman berpotensi untuk menjadi desa wisata dengan melihat beberapa potensi wirausaha yang telah dimiliki desa.

\section{DAFTAR PUSTAKA}

Abdoellah, O. S., Sunardi, Widianingsih, I., Cahyandito, M. F., Wiyanti, D. T., \& Nurseto, H. E. (2019). Pengembangan Ekowisata Berbasis Masyarakat Di Desa Tarumajaya , Hulu Sungai Citarum: Potensi Dan Hambatan. Kumawula: Jurnal Pengabdian Kepada Masyarakat, 2(3),236-247. https://doi.org/http://10.24198/kumawula. v1i3.24553

Buchari, R. A., Darmawan, I., \& Zakaria, S. (2019). Pengembangan Potensi Kewirausahaan di Desa Cikeruh Melalui Program "Cikeruhpreneur" dan Produk Unggulan "Pa'engsit." Kumawula : Jurnal Pengabdian Kepada Masyarakat, 2(3),270-280.

https://doi.org/http://10.24198/kumawula. v1i3.24701

Briedenhann, J. and Wickens, E. 2004. Tourism routes as a tool for the economic development of rural areas: Vibrant hop or impossible dream? Tourism Management. 25: 71-79

Dahsper, Katherine. 2014. Rural Tourism: An International Perspective. Cambridge Scholars Publishing. UK

Dimitrovski, et.al. 2012. Rural Tourism and Regional Development: Case Study Of Development Of Rural Tourism in The Region Of Gruza, Serbia. Procedia Environmental Science. 14: 288-297. 
Fildzah A'inun N, et al. 2015. Pengembangan Desa Wisata Melalui konsep Community Based Tourism. Prosiding KS: Riset dan PKM. Volume. 2. Nomor. 3 Hal: 301444

George, E. Wanda.et.al.2009. Rural Tourism Development Localism and Cultural Change. Channel View Publication. Bristol. UK

Marshall, Gordon. 1998. Oxford Dictionary Of Sociology. Up-to-Date, Comprehensive and Readable. Oxford University Press. Inc. New York

Guelan, Y., Kustepeli, Y. and Akgungor, S. (2009). Public Policies and Development Of The Tourism Industry in The Agean Region. European Planning Studies. 17(10): 1509-1523.

Hamzah, A.S dan M. Irfan. 2018. Tourism Village Expansion In The Concept Of Sustainable Tourism Development (Indonesia Experience). Jurnal Notariil. Volume 3. No. 1 Mei 2018. DOI: 10.22225/jn.3.1.597.1-12

Lane, Bernard and Elisabeth Kastenholz. 2018. Rural Tourism: The Evolution of Practice and Research Approaches Towards a New Generation Concept?.

Maryati, Kun dan Juju Suryawati. 2006. Sosiologi. Jakarta: Journal of Sustainable Tourism, Volume 23, Issue 8-9 (September-October 2015) pp.11331156Esis

Ogburn, William F \& Mayer F. Nimkoff (1964). A Handbook Of Sociology.Routledge \& Kegan Paul. Ltd. London

Priasukmana, S, \& Mulyadin, R. M. (2001). Pembangunan Desa Wisata: Pelaksanaan Undang-Undang Otonomi Daerah, Info Sosial Ekonomi, vol 2, No. 1, 2001.

Scott, John. \& Gordon Marshal. 2009. Oxford Dictionary of Sociology. Oxford University Press. Inc. New York
Robert, Lesley \& Derek Hall. 2001. Rural Tourism and Recreation: Principles to Practice. CABI Publishing, London. UK

Sutiyono. 2008. Pemberdayaan Masyarakat Desa dalam Pelaksanaan Program Desa Wisata di Daerah Istimewa Yogyakarta.

Vigdor, Jacob (2008). Measuring Immigrant Assimilation in the United States. New York: NY: Manhattan Institute, Civic Report No. 53. 